\title{
View on the Essence of Post-modernism Design from Artistic Process
}

\author{
Hui Li \\ School of Arts and Design \\ Huanghe Science and Technology College \\ Zhengzhou, Henan, China 450063
}

\begin{abstract}
Art is the behavior of mankind which is closest to the world. In human existence, only the art has the most obvious manifestations of the realm within the various relationships in the world. The rebellion of postmodernist design to modernism was influenced by postmodern art. Its development is a kind of artistic process, a way of using art to break modernism design frame, and its essence is artistic existence. This paper analyzes the post-modernist design artistic process from the angle of modernism design thought, the art thought of post-modernism design and the artistic process of design, and makes discussion on the artistic essence of post-modernism design.
\end{abstract}

Keywords-artistic; essence; design; modernism; frame; postmodernism art

\section{INTRODUCTION}

The term "design" is derived from the Renaissance word disegno, early refers to the "reasonable arrangement of visual elements and the basic principles for this rational arrangement". It is a technical term used in the field of painting and sculpture. In the industrial production period, the design content changed from purely artistic behavior into a creation behavior involved in industrial product manufacturing. In human existence, only the art has the most obvious manifestations of the realm within the various relationships in the world. Art is the behavior of mankind which is closest to the world. The rebellion of postmodernist design to modernism was influenced by postmodern art. This paper explores the essence of postmodernist design from the perspective of artistic orientation of design.

In fact, since the birth of design, the artistic tendency of design has been subject to widespread controversy in the design field. Postmodernist design was popular in the construction industry from the 60 s of last century, when the idea of artistic design is very popular and designers mostly have construction background. In order to explore the essence of postmodernist design, we must understand the artistic process of post-modernist design development, which have to mention the design thinking mode of modernist and the art thought which post-modernist design followed.

\section{THE DESIGN THINKING Mode OF MODERNIST}

Modernist design emphasizes functionality, featured by the minimalism style, pursuit the design's high degree of democratization and social engineering, is the exploration of idealism; committed to a kind of design which is nonindividual, can be industrialized and mass produced and represent the characteristics of industry society. The ULM Academy of Design is committed to the design exploration of rationalist and functionalist, and developed to a system design with highly efficiency and strong orderliness. The United States because of its great commercial advantages change the abstract style of minimalism into a popular international fashion, "good design" has become the byword of a high taste life. At this point, modernism has become an international style. This style spread from the United States to the entire Europe, and later spread to Japan, now the third world and even the fourth world countries can not wait to follow in order to flaunt their democracy and modern. Modernist straight lines are filled the whole Western society. The greatest contribution of Modern design to human is human engineering and system design theory, system design provide comfort and convenience for the activity places of industrial social groups, human engineering makes people feel extremely comfortable and fitness with their hands and feet when they are in action.

\section{The Art Thought That Post-Modernist Design FOLLOWED}

Le Corbusier, the modernist design master, once enthusiastically praised machine design aesthetics, but in the 1930s he began to question the value of machine civilization and to reintroduce the process technology back into nature and architecture. Corbusier once said in an Artist Salon: "Architect is nothing to be impressed, only you must first be a poet...In practice, to be an engineer or an architect, he must first have a poet's quality. In short, poet, poet, should first be a poet."

The center of modernism is in Paris, the center of postmodernism moved to New York. What kind of art does postmodernism design follow? In order to understand the postmodern art thought, you must understand the father of postmodernism - Duchamp's art. Clarify the post-modern art thought so that we could finally understand the artistic essence of post-modernist design.

Speak of Duchamp, as one of the most difficult to summarized artists, I think that Duchamp is the best embodiment of post-modernist art characteristics, he can be considered as the initiator of post-modernist art. Duchamp once add two pieces goatee on the picture of Leonardo da 
Vinci's famous painting "Mona Lisa", and titled it "L· H· O· O• Q"; Duchamp "Stick the artistic label" on a readymade bicycle wheel in 1913; In 1963 he exhibited a piece of work - "spring" in Stockholm equipment exhibition which has a very sensational effect at that time, he directly moved a ready-made urinal to the exhibition site, which has a very epoch-making significance for post-modern artistic ideological trends at that time. Before Duchamp, the artist's artistic innovation was to overthrow the artistic style, pattern and standard of the predecessors, but no one doubts the art itself. What Duchamp did was precisely this point.

In Duchamp's art process, he studied Impressionism, Fauvism and Cubism. In 1912, when he was 25 years old, he has been recorded in the book which has earliest introduction of Cubism artists. But in a Cubist exhibition at the beginning of 1912, Duchamp's "Naked Woman Downstairs" was considered too close to the Italian Futurist and refused to exhibit. This concept of martial art made Duchamp refused to join any art groups or art salon since then. Even though Europe Dadaism in 1916 regarded him as their spiritual leader, Duchamp was unwilling to intervene in their activities. When recalling the unpleasant events of 1912, Duchamp said: "The Cubism was just popular for two or three years but they already have a very clear boundary, what to do can be expected, what a naive foolish this was." "... I never kept myself in an established pattern for a long time, to imitate, to be affected ..." "A person wants to be a painter because he wants the so-called freedom." "But there is no such plan in advance." Duchamp is opposed to a planned creation. When talked about his own creations, he said: "... When I create it, I do not have any idea. Something appeared during the creation process ... I do not have the thought to create a new movement in painting. Things that Impressionism, Futurism or any other 'doctrine' want to do. "For twelve consecutive years from 1927, he did not compel himself to make any artistic creations. In front of Duchamp's works, the aesthetic standards lost their meaning. "Art can be anything, art is not high, art is not worthy of our too much esteem." After the birth of ready-made work, many people add meanings to it, Duchamp warning them that you that the Ready-made product does not represent any declaration of aesthetics, "If life is beautiful, then the ordinary product can be beautiful too." "Ready-made product is not there to let you slowly find its beautiful, it is to against the visual temptation, it is just a thing, it was there, You do not need to do aesthetic contemplation, observation, it is nonaesthetic." The foundation of Duchamp's artistic creation is to break the art framework. He valued thinking more than skill, focused on life more than art. The freedom of his entire life is no not inferior to his art creations. Commentator Roach praised: "The best work of Duchamp is his life." For this evaluation, Duchamp is very satisfied. He said: "I like to live, breathe, or even like to work ... my art can be alive ..."

\section{THE ARTISTIC PROCESS OF DESIGN}

There are two periods in the history of design which try to achieve the artistic of design, the first period is "British Arts and Crafts Movement" and "Art Nouveau" period which separately chaired by William Morris and Van de Wilde. Design was from the advocate of designers for handicrafts in early days. In the design history, handicrafts have a special status, not only is the pioneer of modern design, such as Morris and Wilde have gave a high evaluation of handicrafts and regard medieval arts and crafts design recovery as the design purpose, but also the postmodern Memphis design team emphasize handicraft design as well. From the industrial mass production began, a large number of cheap and practical involved in people's lives. As the factory owners only take into account the practical benefits of the products, there is no time to consider the artistic nature of industrial products, which making the artistic of machinery manufacturing products greatly reduced. It is generally felt that the prevalence of industrial products have a negative impact on social civilization, reducing the public's aesthetic ability and taste. Which makes the artists of this period proposed the creation of artistic products. They think that design is a form of art; design is the artist's creative behavior. Their idea is to class design into the category of art, and use art standard to measure industrial products. They are keenly aware the alienation caused by big industrial production. This push them return to the traditional production mode and seek help, hope use arts and crafts to enhance the aesthetic taste of the entire society. The movement in this period failed, the reason is they use artist form to cover the development of technology. And later the modernist design tends to its opposite: use the technology to cover the artistic display.

The second period that advocates the artistic design is postmodernist design period. Designers engaged in creative activities, the process of thinking was out of tune with the framework. The work of designers is groundbreaking is the basic reason why they mostly call their activities are artistic expression rather than the mechanical production.

The rebellion of postmodernist design to modernism was influenced by postmodernism art and inspired by the "Antiart" ideological trend in1950s and British pop art. Art's abandonment of natural phenomena began from Cézanne, Cezanne in his works weakened the space operation of traditional focus to the images, cut off the key link between art and nature "real" images. But the images in his works remain a completed form, which is still able to be related to the natural things. Picasso's art completely destroyed the intervention of natural things to art. When someone asked Picasso "what is art", Picasso asked in reply "What is not art". In his eyes, the boundaries of art are indefinite. And in Duchamp's eyes, the art has no territory at all. He is the first person in the history of art to reject the concept of art, use "ready-made products" to erase the boundaries between art and non-art.

In the postmodern designs, there is no limit to the visual form, language context, mass media, digital imaging, acoustooptic, as long as the specific information can be conveyed. Deduct the optimism and fun of popular culture, or re-try to learn ancient Greek, Latin style or decorative grammar, and some also subject the influence of a number of new ideas, such as green environmental protection issues, pop music, etc ; However, they all have a characteristic: Irrationality. Postmodernist design is to break all norms, even the art norms. It pursuits the artistic display, not to comply with the framework of any discipline. Confuse the boundaries of art and non-art, in particular, confuse the difference between art and 
life. Only when the arts and life blend together, the creativity of art can be reflected in the broadest extent. Andy Warhol, the famous US POP artist's work "Marilyn Monroe", "Coca-Cola", "One-Dollar" ... and so on, no matter the subject or the form of painting both are not in line with the definition of painting, he just closely linked to the lifestyle of the United States. He believed that art should reflect the flat and equal of public life. His works represented the life of the United States for 25 years, which has a universal meaning, everything has been done in the silent! Like Gauguin went to the original Tahiti island to find the nature which inspire his creative source, "Water Villa" designer Wright once said: "Nature is the theme of architecture-design provides the material, The architectural form that we know today is derived from this ... there is no richer and more inspired aesthetic source than the understanding of nature laws... ". American Kim Levin in the" Farewell to modernism "said:" Postmodernism means style free and free-style. They are funny and full of suspicion, but do not deny anything. They admit clumsy and rough this fact, and take a hobby attitude ... because of its subjective and internal nature, it blurred the boundary between world and their own." Gaetano Pesee's colorful New York sunset sofa introduced natural landscape to the interior. Post-modern design saved people from a simple, mechanical boring life, back to the real life.

\section{CONCLUSION}

This paper discusses the thinking mode of modernist design, makes a thorough analysis to the artistic thinking which post-modernist design followed, and analyzes the artistic process of design. The origin of design activity is to understand the world. Western designers have a strong sense of identity about the artist's constant understanding of the world, so they are always willing to call their own design is engaged in artistic activities. Artistic design is not a denial of design, but found the authenticity of design; Artistic design is not obliterate the design features, but in order to show more about the nature of design. Design itself is from the listening and participation of the world, it represents the hope just like art, it carries the mission to break the frame and lead people to embark on a journey with full of hope and beauty. Postmodernist design thinking was benefit from post-modern art, its development is an artistic process, its essence is the artistic existence. Postmodernist design uses the artistic as the way to break the frame, art guide the road for people.

\section{REFERENCES}

[1] Ma Yongjian "20 Lectures for Postmodern Art " Shanghai Academy of Social Sciences Press, January 2006.

[2] Dao Zi. "Postmodern Art Pedigree" Chongqing Publishing Company January 2007.

[3] (US) Kim Levin, Chang Ningsheng, Xing Li, Li Hong compiled. "Postmodern transformation" Jiangsu Education Press, December 2005.

[4] (US) H. H. Arsenal, Zou Denong translated. "History of Western Modern Art" Tianjin People's Fine Arts Publishing Company 1994.

[5] (EN) E. H. Gombrich, Fan Jingzhong translated. "At story" Guangxi Fine Arts Publishing Company. April 2008.

[6] Wang Shouzhi "World graphic design history" Beijing China Youth Press 2002.
[7] Zhu Ming, Jiang Jun, Zhu Xu, Dong Zhanjun "Re-Awakening of Designer" Beijing China Social Press 1996. 